\title{
Short communication: Effect of subclinical mastitis on proteolysis in ovine milk
}

\author{
A. Martí-De Olives, ${ }^{1}{ }^{1}$ Y. Le Roux, $†$ J. Rubert-Alemán, ${ }^{\star}$ C. Peris, $\neq$ and M. P. Molinał \\ *Departamento de Tecnología Agroalimentaria, Escuela Politécnica Superior de Orihuela, Universidad Miguel Hernández de Elche, Ctra. Beniel, \\ km 3.2, 03312 Orihuela, Spain \\ †Unité de Recherche Animal et Fonctionnalités des Produits Animaux, Institut National Polytechnique de Lorraine, ENSAIA-INRA, 54505 \\ Vandoeuvre-lès-Nancy Cedex, France \\ łInstituto de Ciencia y Tecnología Animal, Universidad Politécnica de Valencia, Camino de Vera s/n., 46022 Valencia, Spain
}

\section{ABSTRACT}

The aim of this work was to evaluate the effect of intramammary infection (IMI) on the endogenous proteolysis of milk. Four control checks were carried out in the half-udder milk of 10 ewes that acquired unilateral subclinical mastitis. Two of these checks were conducted before the infection was established and 2 after. Ten healthy ewes were tested as a control group. The presence of a subclinical IMI involved an increase of the products of casein hydrolysis, the proteose-peptone $(\mathrm{p}-\mathrm{p})$ fraction and minor $(m)$ caseins, and a decrease of $\beta$-casein. As a result, a significant increase in the proteolysis index (PI), calculated as the ratio of $m$ casein to the sum of caseins $(\alpha+\beta+\kappa)$, took place. $\alpha$-Casein and $\kappa$-casein were not significantly affected by IMI. Correlations confirmed the scenario: $\log _{10}$ of somatic cell count (SCC) was positively correlated with p-p content and negatively with $\beta$-casein, whereas $\log _{10}$ SCC was not correlated with $\alpha$-casein or $\kappa$-casein. On the other hand, p-p content was positively correlated with $m$-casein and PI and negatively with $\beta$-casein, but no correlation was detected between p-p content and $\alpha-$ or $\kappa$-casein. Furthermore, between casein fractions, $m$ casein was only significantly correlated with $\beta$-casein. These results suggest that use of indices of proteolysis of caseins such as p-p, m-casein, and PI, could be applied together with SCC to evaluate the cheese-making quality of milk.

Key words: ovine milk, intramammary infection, somatic cell count, proteolysis

\section{Short Communication}

Ewe milk is mainly destined for cheese manufacturing. The cheese-making quality of milk depends, among other factors, on the concentration of intact casein

Received February 14, 2011.

Accepted July 25, 2011.

${ }^{1}$ Corresponding author: ana.marti@umh.es
(Bianchi et al., 2004; Leitner et al., 2004; Albenzio et al., 2009). The milk proteolytic enzymes are responsible for the hydrolysis of caseins that reduces the stability of micelles during milk storage and leads to the diminution of coagulation properties of milk (Storry et al., 1983; Grandison et al., 1984). Several studies have documented that IMI in ewe milk is associated with high proteolysis activity that impairs coagulation properties of milk; that is, a longer rennet coagulation time, weak coagulum (Albenzio et al., 2004, 2009), and a decrease in the frequency of samples reactive to rennet (Bianchi et al., 2004). In general, poor coagulation properties lead to increased curd yield loss (Leitner et al., 2004, 2008). Plasmin (PL) appears to be the major enzyme involved in sheep milk proteolytic phenomena associated with udder inflammation (Bianchi et al., 2004; Leitner et al., 2004). According to Silanikove et al. (2006), $\beta-\mathrm{CN}$ is the preferred substrate for PL, and its hydrolysis results in the production of $\gamma$-caseins and proteose-peptones $(\mathbf{p}-\mathbf{p}) ; \alpha_{\mathrm{S}^{1}}$-casein and $\alpha_{\mathrm{S} 2}$-casein are also susceptible to proteolysis by PL, and $\lambda$-caseins are products of hydrolysis of $\alpha_{S 1}$-casein. However, $\kappa$-casein is resistant to proteolysis by PL. Le Roux et al. (1995) indicated that the relative proportion of $\gamma$-CN to $(\alpha$ $+\beta+\kappa)$-CN and the $\mathrm{p}$-p fraction were both valid estimation predictors of endogenous proteolysis in cow milk with elevated SCC. In the same way, Leitner et al. (2004) found high correlations between SCC and both PL activity and p-p content in sheep milk. In addition to PL, other endogenous proteolytic enzymes from somatic cells can impair the coagulation behavior of milk (Albenzio et al., 2009). Bovine caseins are reported to be degraded by leukocyte proteinases in the following order: $\alpha>\beta \gg \kappa-C N$ (Considine et al., 2004). In ewe milk, Albenzio et al. (2009) indicated that elastase and cathepsin $\mathrm{D}$ affected primary $\alpha$-casein. In spite of the reported correlation between SCC and endogenous proteolysis (Bianchi et al., 2004), the relationships among bacterial infection, intramammary response, proteolysis of casein, and consequently cheese yield and quality, are complicated (Le Roux et al., 2003). Leitner et al. 
(2006) expressed doubt that SCC could be used as a single reliable indicator of cheese yield and quality and demonstrated that SCC provided the poorest prediction of milk quality for cheese production compared with some indices of proteolysis of casein, such as p-p content in milk and PL activity. Thus, better knowledge on the relationship between IMI, SCC, and casein proteolysis could indicate several proteolysis indices to be used by the dairy industry, together with SCC, as predictor measures of milk quality.

The present study focused on establishing the effect of subclinical IMI on ewe milk p-p fraction and on the relative proportions of $\alpha_{-}, \beta-, \kappa_{-}$, and minor $(\boldsymbol{m})$ caseins, the latter being a group of casein hydrolysis products analogous to bovine $\gamma$-caseins (Gordon and Groves, 1975). Use of the half-udder as the experimental unit should enable us to quantify the negative effect of subclinical mastitis on milk proteolysis with high statistical reliability (Leitner et al., 2004).

This work was carried out on the experimental farm flock of Manchega ewes of the Institute for Animal Science and Technology of the Polytechnic University of Valencia (Spain). The animals were stabled throughout the lactation period and ewes were machine-milked twice daily at 0830 and $1730 \mathrm{~h}$ from the third day after lambing. The presence of IMI was tested by bacteriological and SCC measures twice a week during the first $15 \mathrm{~d}$ after lambing and then once a week for the next 14 wk. After the first $15 \mathrm{~d}, 55$ ewes free of IMI were selected from the flock. When ewes were in their third or fourth week of lactation, milk from half udders was hand-sampled $(200 \mathrm{~mL})$ in the morning milking. Sampling was repeated 1 wk later. In each sampling, a $0.01 \%$ final concentration in milk of a bacteriostatic product (Thimerosal, Sigma Chemical Co., St. Louis, MO) was added to the 200-mL samples to avoid any bacterial proteolysis in milk during stocking time. Milk samples were kept $24 \mathrm{~h}$ at $4^{\circ} \mathrm{C}$ to favor endogenous proteolysis development and then were frozen at $-80^{\circ} \mathrm{C}$ until analysis to prevent enzymatic activity after the first $24 \mathrm{~h}$.

To increase the incidence of IMI, and consequently the number of cases to study, 2 management practices were applied. The first was the immersion of teats in a bacterial suspension such that, between wk 4 and 8 after lambing, the teats of all 55 ewes were immersed in a suspension of Staphylococcus simulans $\left(5 \times 10^{7} \mathrm{cfu} /\right.$ $\mathrm{mL}$ ) on 4 alternating days, at the morning and evening milking (8 milkings) and immediately before application of the milking unit. The second practice was no dipping of teats after milking throughout the trial. During the next weeks of the trial, 10 ewes that were declared infected with unilateral IMI and 10 healthy ewes were selected and were blocked into 10 pairs based on parity, lactation state, and milk production. In each pair, one ewe was infected and the other one was healthy. The experiment was continued with these 20 animals only. Subsequently, the half-udder milk of the 20 selected ewes was hand-sampled twice $(200 \mathrm{~mL}$ each), the first sampling being in the same week in which the halves were considered infected, and the second one $15 \mathrm{~d}$ later. A $0.01 \%$ final concentration in milk of a bacteriostatic product (Thimerosal, Sigma Chemical Co.) was added to the 200-mL samples. Milk samples were kept $24 \mathrm{~h}$ at $4^{\circ} \mathrm{C}$ to favor endogenous proteolysis development, and $\mathrm{p}-\mathrm{p}$ content and casein fractions were determined immediately thereafter. At this time, the frozen milk samples (from the 20 selected ewes) that were collected before infection were thawed and analyzed. Thus, the experiment was carried out with 20 animals and divided into 2 periods: a preinfection period, when the glands of the 20 ewes were healthy, and a postinfection period in which 10 ewes had unilateral IMI and their pairs were free of IMI. Mastitic glands remained infected during the rest of the trial.

The bacterial suspension was made from a Staph. simulans strain obtained from a gland with subclinical mastitis from a commercial flock. Staphylococcus simulans forms part of the group of CNS that are considered opportunist microorganisms normally found on healthy teat skin as well as on the hands of milkers. Consequently, Staph. simulans may easily colonize the teat canal and infect the mammary gland. The bacterial suspension $\left(5 \times 10^{7} \mathrm{cfu} / \mathrm{mL}\right)$ used to dip the teats was prepared according to Hogan et al. (1990). Stock cultures of Staph. simulans were stored at $-20^{\circ} \mathrm{C}$ in $50 \%$ glycerin. A 6-mL tube of trypticase soy broth (TSB) was inoculated from a vial of stored stock culture and incubated at $37^{\circ} \mathrm{C}$ for $7 \mathrm{~h}$. One milliliter of this starter culture was used to inoculate $500 \mathrm{~mL}$ of TSB, which was then incubated for 16 to $18 \mathrm{~h}$ at $37^{\circ} \mathrm{C}$ on a gyratory shaker. Cells were pelleted by centrifugation, washed twice with a $0.1 \%$ water solution of proteose-peptone (no. 3, Difco Laboratories, Detroit, MI), and resuspended in proteose-peptone. A standard plate count was conducted on the stock suspension before it was stored at $5^{\circ} \mathrm{C}$. The plate count was used to determine the dilution required to prepare daily challenge suspensions containing $5 \times 10^{7} \mathrm{cfu} / \mathrm{mL}$ in TSB. The challenge suspension was prepared immediately before use.

To obtain milk samples for bacteriological analysis, teats were carefully cleaned with $70 \%$ ethanol and the first 3 streams of foremilk were discarded. Approximately $10 \mathrm{~mL}$ of milk was collected aseptically from each gland before the morning milking. Samples were kept at $4^{\circ} \mathrm{C}$ for a maximum of $12 \mathrm{~h}$ until bacteriological analysis. Twenty microliters of each sample was plated on blood agar plates (5\% washed sheep erythrocytes; 
bioMerieux, Lyon, France). The plates were incubated aerobically at $37^{\circ} \mathrm{C}$ and examined at $24 \mathrm{~h}, 48 \mathrm{~h}$, and 7 d. Cultures with 5 or more identical colonies were considered positive for IMI. A new IMI in a half udder was diagnosed when the same bacterial species was isolated from 2 consecutive samples positive for IMI $(\geq 250$ $\mathrm{cfu} / \mathrm{mL})$. A gland diagnosed with IMI was considered infected from the first sampling in which the culture was positive for IMI. Bacteria were identified according to the National Mastitis Council recommendations (Harmon et al., 1990). Identification of staphylococci was carried out using commercial micromethods (API Staph; bioMèrieux). Somatic cell count was determined with a Fossomatic 90 (A/S N Foss Electric, Hillerød, Denmark) in all samples taken for bacteriological analysis. Samples remained under refrigeration for 24 to $48 \mathrm{~h}$ before being analyzed (IDF, 1995).

Caseins were extracted from skim milk by acid precipitation of milk at $\mathrm{pH} 4.6$, according to the Rowland (1938) procedure. The purified caseins were redissolved by addition of $4 \mathrm{~mL}$ of distilled water and $1 \mathrm{~mL}$ of $1 \mathrm{M}$ $\mathrm{NaOH}(\mathrm{pH}$ 7.0) and were transferred to a Petri plate. The solubilized caseins were frozen and lyophilized before being analyzed by chromatography. The relative content of each casein fraction was determined by fast protein liquid chromatography analysis on a Mono Q HR 5/5 anion-exchange column (Pharmacia Ltd., Milton Keynes, UK) according to the procedure of Papoff et al. (1993) for ewe milk. Using this method, $\alpha-, \beta-, \kappa_{-}$, and $m$-caseins can be separated. The p-p fraction was extracted according to the fractionating scheme recommended by Rowland (1938) and modified by Andrews (1978); the supernatant S1 obtained after centrifugation $(4,000 \times g$ for $15 \mathrm{~min})$ of a previously skimmed, heated $\left(95^{\circ} \mathrm{C}\right.$ for $\left.30 \mathrm{~min}\right)$, and acidified $(\mathrm{pH}=4.4 ; 1$ $M$ acetic acid) milk sample was precipitated with TCA (final concentration of $12 \%$ ). Supernatant S1 was then centrifuged $(6,000 \times g$ for $15 \mathrm{~min})$ and supernatant S2 was washed several times with an ethanol-ether mixture (vol $/ \mathrm{vol}$ ) and frozen at $-20^{\circ} \mathrm{C}$. The $\mathrm{N}$ content of the p-p fraction was calculated by subtracting the $\mathrm{N}$ content of supernatant $\mathrm{S} 2$ from the $\mathrm{N}$ content of supernatant S1. Both of these were measured by the Kjeldahl method (IDF, 1993) with a Digestion System 201015 digester (Foss Electric) and a Kjeltec Auto 1030 Analyzer (Foss Electric). The conversion factor used for converting the $\mathrm{N}$ content into protein content was 6.54 (Ribadeau-Dumas and Grappin, 1989). Each sample was analyzed twice.

The influence of infection status of the gland was statistically analyzed in the 2 periods on $\log _{10}$ SCC; p-p fraction; $\alpha-, \beta-, \kappa_{-}$, and $m-\mathrm{CN}$; and proteolysis index $(\mathbf{P I})$, calculated as the ratio $(\%)$ of $m$-CN to $(\alpha+$ $\beta+\kappa)$-CN. In the preinfection period, the effect of unilateral IMI was analyzed according to the following mixed model:

$$
\begin{gathered}
\mathrm{Y}_{\mathrm{ijk} k \mathrm{~m}}=\mu+\mathrm{EIS}_{\mathrm{i}}+\mathrm{E}_{\mathrm{j}}\left(\mathrm{EIS}_{\mathrm{i}}\right)+\mathrm{GIS}_{\mathrm{k}}+\mathrm{GLA}_{1} \\
\left(\mathrm{E}_{\mathrm{j}} \mathrm{GIS}_{\mathrm{k}}\right)+\mathrm{EIS} \times \mathrm{GIS}_{\mathrm{ik}}+\mathrm{C}_{\mathrm{m}}+\mathrm{e}_{\mathrm{ijklm}},
\end{gathered}
$$

where $Y_{\mathrm{ijklm}}=$ arithmetical mean of each studied variable; $\mu=$ mean; EIS $_{\mathrm{i}}=$ fixed effect of ewe infectious status ( $\mathrm{i}=1$, healthy ewes; $\mathrm{i}=2$, infected ewes); $\mathrm{E}_{\mathrm{j}}$ $\left(\right.$ EIS $\left._{\mathrm{i}}\right)=$ random effect of the ewe nested in $\operatorname{EIS}_{\mathrm{i}}(\mathrm{j}=$ $1,2,3, \ldots, 20) ;$ GIS $_{\mathrm{k}}=$ fixed effect of gland infectious status $[\mathrm{k}=1$, infected glands from infected ewes (type A glands) or healthy glands from healthy ewes (type C glands); $\mathrm{k}=2$, healthy contralateral glands to glands A (type B glands) or healthy contralateral glands to glands C (type D glands)]; letters $\mathrm{C}$ and $\mathrm{D}$ were randomly assigned to each gland of healthy ewes; $\mathrm{GLA}_{1}\left(\mathrm{E}_{\mathrm{j}}\right.$ GIS $\left._{\mathrm{k}}\right)=$ random effect of gland nested in $\mathrm{E}_{\mathrm{j}}$ and in $\mathrm{GIS}_{\mathrm{k}}$ $(1=1,2,3, \ldots, 40) ; C_{m}=$ fixed effect of control day $(\mathrm{m}=1,2) ; \mathrm{EIS} \times \mathrm{GIS}_{\mathrm{ik}}=$ ewe infectious status $\times$ gland infectious status interaction; and $\mathrm{e}_{\mathrm{ijklm}}=$ residual effect.

For the postinfection period, the statistical model used was the same with adding the mean value of preinfection period as a covariable $(\mathrm{COV})$ :

$$
\begin{gathered}
\mathrm{Y}_{\mathrm{ijklm}}=\mu+\mathrm{EIS}_{\mathrm{i}}+\mathrm{E}_{\mathrm{j}}\left(\mathrm{EIS}_{\mathrm{i}}\right)+\mathrm{GIS}_{\mathrm{k}}+\mathrm{GLA}_{\mathrm{l}} \\
\left(\mathrm{E}_{\mathrm{j}} \mathrm{GIS}_{\mathrm{k}}\right)+\mathrm{EIS} \times \mathrm{GIS}_{\mathrm{ik}}+\mathrm{C}_{\mathrm{m}}+\mathrm{COV}+\mathrm{e}_{\mathrm{ijklm}} .
\end{gathered}
$$

These statistical analyses were carried out using the Mixed procedure of SAS (SAS Institute, 1999). Pairwise correlations were calculated on the data file from infected ewes with the Corr procedure of SAS (SAS Institute, 1999).

Characteristics of infected ewes are shown in Table 1. All ewes presented unilateral subclinical mastitis that was declared between wk 5 and 14 from lambing. The SCC geometrical mean values in infected glands varied between 331,000 and 3,257,000 cells/mL. Most of the infections, 6 out of 10, were caused by the same species used to carry out the immersions (Staph. simulans), whereas the other 4 infections occurred naturally and were caused by Staphylococcus xylosus (in 2 ewes), Staphylococcus epidermidis, and Streptococcus spp. Several authors have indicated that CNS bacteria, mainly Staph. epidermidis, Staphylococcus chromogenes, Staph. simulans, and Staph. xylosus are the most abundant bacterial isolates associated with subclinical mastitis in sheep flocks in various countries (Fthenakis, 1994; González-Rodríguez et al., 1995; Leitner et al., 2001, 2004).

During the preinfection period, as expected, the effect of the interaction factor between ewe infectious 
Table 1. Characteristics of infected ewes, type and cell load of bacteria involved, and SCC in milk from infected glands during the postinfection period

\begin{tabular}{|c|c|c|c|c|c|c|c|}
\hline \multirow[b]{2}{*}{ Ewe } & \multirow[b]{2}{*}{$\mathrm{LN}^{1}$} & \multirow{2}{*}{$\begin{array}{l}\text { Infected } \\
\text { gland }\end{array}$} & \multirow[b]{2}{*}{ Species } & \multirow{2}{*}{$\begin{array}{c}\text { Bacterial } \\
\text { cell load } \\
(\mathrm{cfu} / \mathrm{mL})\end{array}$} & \multicolumn{2}{|c|}{$\mathrm{SCC}\left(\times 10^{3} \text { cells } / \mathrm{mL}\right)^{2}$} & \multirow{2}{*}{$\begin{array}{c}\text { Infection } \\
\text { week }^{3}\end{array}$} \\
\hline & & & & & $\mathrm{AM}$ & GM & \\
\hline 1 & 2 & Left & Staphylococcus xylosus & 2,050 & 432 & 331 & 14 \\
\hline 2 & 2 & Left & Staphylococcus simulans & 3,600 & 4,698 & 1,288 & 7 \\
\hline 3 & 2 & Right & Staph. xylosus & 4,250 & 4,755 & 3,162 & 10 \\
\hline 4 & 1 & Left & Staph. simulans & $>5,000$ & 5,364 & 2,818 & 8 \\
\hline 5 & 2 & Right & Staphylococcus epidermidis & 2,700 & 1,587 & 1,096 & 9 \\
\hline 6 & 2 & Right & Staph. simulans & 1,650 & 757 & 457 & 7 \\
\hline 7 & 1 & Left & Staph. simulans & 2,250 & 1,739 & 646 & 8 \\
\hline 8 & 1 & Right & Streptococcus spp. & 3,350 & 5,013 & 1,995 & 5 \\
\hline 9 & 2 & Left & Staph. simulans & $>5,000$ & 3,788 & 3,257 & 13 \\
\hline 10 & 1 & Right & Staph. simulans & 2,400 & 474 & 263 & 7 \\
\hline
\end{tabular}

${ }^{1}$ Lactation number: 1 = first lactation, 2 = second and later lactations.

${ }^{2} \mathrm{AM}=$ arithmetic mean; $\mathrm{GM}=$ geometric mean.

${ }^{3}$ Lactation week from each gland is considered infected.

status and gland infectious status $\left(\mathrm{EIS} \times \mathrm{GIS}_{\mathrm{ik}}\right)$ was not significant, so the milk of all glands presented similar values of studied parameters in this period. In the postinfection period, EIS $\times$ GIS $_{\mathrm{ik}}$ had a significant effect upon $\log _{10}$ SCC $(P<0.001)$, p-p content $(P<$ $0.01), \beta-\mathrm{CN}(P<0.001), m-\mathrm{CN}(P<0.001)$, and PI $(P<0.001)$, but no significant effect on $\alpha-\mathrm{CN}$ and $\kappa-\mathrm{CN}$. The mean values of parameters determined in milk from each type of gland, depending on its infectious status are shown in Table 2. As expected, $\log _{10}$ SCC presented a significantly higher mean value $(P$ $<0.001)$ in infected glands than in healthy ones. The mean $( \pm$ SE) p-p content was significantly higher $(P<$ 0.01) in milk of infected glands than in milk of healthy glands. With respect to casein fractions, the mean value $( \pm \mathrm{SE})$ of $m$-CN was almost $60 \%$ higher $(P<0.001)$ in infected glands than in healthy contralateral glands and than in glands from healthy ewes. On the other hand, $\beta$-casein was 17 to $18 \%$ lower in infected glands than in healthy ones $(P<0.001)$. Furthermore, a higher PI $(P<0.001)$ was observed in milk from infected glands than in that from healthy glands, a finding consistent with the observed increase of $m$-CN and decrease of $\beta$-CN. In contrast, the differences were not statistically significant for $\alpha-\mathrm{CN}$ and $\kappa-\mathrm{CN}$.

These results indicate an increase of proteolytic activity in ewe milk as a result of IMI at the half-udder level that involved a much greater content of p-p and higher percentage of $m$-CN, as well as a clear decrease in $\beta$-casein percentage. Nevertheless, IMI did not appear to affect $\alpha$ - or $\kappa$-CN content. A similar effect on p-p content in sheep milk was observed by Leitner et al. (2004) in Israeli Assaf ewes $(2.42 \mathrm{~g} / \mathrm{L}$ in infected glands vs. $0.98 \mathrm{~g} / \mathrm{L}$ in healthy glands) and in cows (Le Roux

Table 2. Means $( \pm \mathrm{SE})$ of the considered parameters as affected by the gland health status ${ }^{1}$ during the postinfection period

\begin{tabular}{|c|c|c|c|c|c|}
\hline Parameter & \multicolumn{2}{|c|}{ Infected ewes } & \multicolumn{2}{|c|}{ Healthy ewes } & Significance \\
\hline $\log _{10} \mathrm{SCC}$ & $6.09 \pm 0.08^{\mathrm{a}}$ & $5.01 \pm 0.08^{\mathrm{b}}$ & $4.98 \pm 0.08^{\mathrm{b}}$ & $4.91 \pm 0.08^{\mathrm{b}}$ & $* * *$ \\
\hline $\mathrm{SCC}, \mathrm{GM}^{2} \times 10^{3}$ cells $/ \mathrm{mL}$ & 1,230 & 102 & 95 & 81 & - \\
\hline Proteose-peptone content, g/L & $3.84 \pm 0.36^{\mathrm{a}}$ & $1.04 \pm 0.37^{\mathrm{b}}$ & $0.88 \pm 0.34^{\mathrm{b}}$ & $1.07 \pm 0.50^{\mathrm{b}}$ & $* *$ \\
\hline$\alpha$-Casein, $\%$ & $35.9 \pm 0.61$ & $36.1 \pm 0.64$ & $37.42 \pm 0.56$ & $36.38 \pm 0.52$ & NS \\
\hline к-Casein, \% & $10.0 \pm 0.35$ & $9.6 \pm 0.36$ & $9.2 \pm 0.3$ & $9.0 \pm 0.3$ & NS \\
\hline $\mathrm{PI},{ }^{3} \%$ & $22.42 \pm 1.25^{\mathrm{a}}$ & $12.77 \pm 1.11^{\mathrm{b}}$ & $12.95 \pm 1.10^{\mathrm{b}}$ & $12.02 \pm 1.14^{\mathrm{b}}$ & $* * *$ \\
\hline
\end{tabular}

$\overline{a, b}$ Means within a row with different superscripts differ.

${ }^{1} \mathrm{~A}=$ infected glands; $\mathrm{B}=$ healthy glands contralateral to A glands; $\mathrm{C}=$ healthy glands of healthy control ewes; $\mathrm{D}=$ healthy glands of healthy control ewes, contralateral to $\mathrm{C}$ glands.

${ }^{2}$ Geometric mean.

${ }^{3}$ Proteolysis index, calculated as the ratio of minor caseins to $(\alpha+\beta+\kappa)$-CN.

$* * P<0.01 ; * * * P<0.001$. 
Table 3. Correlation coefficients among all the variables determined in half-udder milk samples from infected ewes $(\mathrm{n}=80)$

\begin{tabular}{|c|c|c|c|c|c|c|}
\hline & $\log _{10} \mathrm{SCC}$ & $\begin{array}{l}\text { Proteose-peptone } \\
\text { content }\end{array}$ & $\alpha$-Casein & $\beta$-Casein & к-Casein & $\begin{array}{l}\text { Minor } \\
\text { caseins }\end{array}$ \\
\hline $\begin{array}{l}\text { Proteose-peptone content } \\
\alpha \text {-Casein }\end{array}$ & $\begin{array}{l}0.71^{* * *} \\
\text { NS }\end{array}$ & NS & & & & \\
\hline$\beta$-Casein & $-0.65 * * *$ & $-0.60 * * *$ & $-0.45^{* * *}$ & & & \\
\hline$\kappa$-Casein & NS & NS & $-0.33^{* *}$ & NS & & \\
\hline Minor caseins & $0.76^{* * *}$ & $0.58^{* * *}$ & NS & $-0.83^{* * *}$ & NS & \\
\hline $\mathrm{PI}^{1}$ & $0.76^{* * *}$ & $0.58^{* * *}$ & NS & $-0.77^{* * *}$ & NS & $0.99^{* * *}$ \\
\hline
\end{tabular}

${ }^{1}$ Proteolysis index, calculated as the ratio of minor caseins to $(\alpha+\beta+\kappa)$-CN.

${ }^{* *} P<0.01 ;{ }^{* * *} P<0.001$.

et al., 1995; Leitner et al., 2006). Previous works on cow milk reported that IMI involves not only a higher p-p concentration, but also a change in the composition of that fraction (Moussaoui et al., 2002, 2003). In this sense, those authors found peptides in the p-p fraction that came specifically from the enzymatic action of PL and polymorphonuclear leukocyte proteases. Concerning caseins, Bianchi et al. (2004) observed similar results on casein fractions from ewe milk when they compared healthy animals with infected ones, with a $6 \%$ decrease in $\beta$-casein content and a $100 \%$ increase in $\gamma$-casein in infected ewes. Similarly to the current study, Bianchi et al. (2004) did not find a significant effect of IMI on $\alpha$-CN and $\kappa$-CN contents.

Our findings differ in part from those obtained in cow milk, in which not only the percentage of $\beta$-casein but also that of $\alpha$-casein was significantly less in milk samples from infected glands or from milk with elevated SCC compared with that from uninfected glands or with low SCC (Le Roux et al., 1995; Urech et al., 1999). The results of the present study do not help to clarify the reasons for that difference, and further studies are required to elucidate the phenomena involved in casein integrity in ewe milk during a subclinical IMI. In particular, it would be interesting to study the interactions among bacteria type, plasmin and nonplasmin activity, different leukocyte populations, and proteolysis indicators.

Correlation coefficients between $\log _{10}$ SCC, p-p content, casein fractions, and PI in milk samples from glands are presented in Table $3 . \log _{10} \mathrm{SCC}$ was high and positively correlated $(P<0.001)$ with $\mathrm{p}$-p content and $m-\mathrm{CN}$ and negatively correlated with $\beta-\mathrm{CN}$, in agreement with observations of Le Roux et al. (1995) in quarter cow milk, whereas correlations between $\log _{10}$ SCC and $\alpha$ - and $\kappa$-casein were not significant, confirming results reported for ovine milk (Bianchi et al., 2004). Furthermore, p-p content was positively correlated $(P$ $<0.001)$ with $m$-CN and PI and negatively correlated with $\beta-\mathrm{CN}$, whereas no significant correlation was detected between $\mathrm{p}-\mathrm{p}$ content and $\alpha$ - or $\kappa$-CN. With respect to $\mathrm{CN}$ fractions, we can observe that $m$-CN was only significantly correlated with $\beta-\mathrm{CN}(P<0.001)$; consequently, PI was correlated with $\beta-\mathrm{CN}$ but not with $\alpha$ - or $\kappa-\mathrm{CN}$. These observations show how the effect of IMI on proteolysis in ewe milk is reflected in the close relationship between SCC and the amount of p-p and $m$-CN when an infectious process is clearly established. However, it is known that SCC in ewe milk is affected by factors other than IMI, so an elevated SCC does not always reflect a decrease in cheese-making quality of the milk. The present research suggests that the use of indices of proteolysis of caseins such as p-p content or CN fractions could be taken into account together with SCC to evaluate the cheese-making quality of milk.

\section{ACKNOWLEDGMENTS}

The authors thank the regional government of Valencia ("Generalitat Valenciana") for its support by means of a research fellowship in which context this work was done.

\section{REFERENCES}

Albenzio, M., R. Marino, M. Caroprese, A. Santillo, G. Annicchiarico, and A. Sevi. 2004. Quality of milk and of Canestrato Pugliese cheese from ewes exposed to different ventilation regimens. J. Dairy Res. 71:434-443.

Albenzio, M., A. Santillo, M. Caroprese, F. d'Angelo, R. Marino, and A. Sevi. 2009. Role of endogenous enzymes in proteolysis of sheep milk. J. Dairy Sci. 92:79-86.

Andrews, A. T. 1978. The composition, structure and origin of PP component 5 of bovine milk. Eur. J. Biochem. 90:59-65.

Bianchi, L., A. Bolla, E. Budelli, A. Caroli, C. Casoli, M. Pauselli, and E. Duranti. 2004. Effect of udder health status and lactation phase on the characteristics of Sardinian ewe milk. J. Dairy Sci. $87: 2401-2408$.

Considine, T., A. Healy, A. L. Kelly, and P. L. H. McSweeney. 2004. Hydrolysis of bovine caseins by cathepsin B, a cysteine proteinase endogenous to milk. Int. Dairy J. 14:117-124.

Fthenakis, G. C. 1994. Prevalence and aetiology of subclinical mastitis in ewes of Southern Greece. Small Rumin. Res. 13:293-300.

González-Rodríguez, M. C., C. Gonzalo, F. San Primitivo, and P. Cármenes. 1995. Relationships between somatic cell count and intramammary infection of the half udder in dairy ewes. J. Dairy Sci. 78:2753-2759.

Gordon, W. G., and M. L. Groves. 1975. Primary sequence of $\beta-, \gamma-$ and minor caseins. J. Dairy Sci. 58:574-582. 
Grandison, A. S., G. D. Ford, D. Millar, and A. J. Owen. 1984. Chemical composition and coagulating properties of renneted milk from cows during early lactation. J. Dairy Res. 51:407-416.

Harmon, R. J., R. J. Eberhart, D. E. Jasper, and B. E. Langlois. 1990. Microbiological Procedures for the Diagnosis of Bovine Udder Infection. Natl. Mastitis Counc. Inc., Arlington, VA.

Hogan, J. S., D. M. Galton, R. J. Harmon, S. C. Nickerson, S. P. Oliver, and J. W. Pankey. 1990. Protocols for evaluating efficacy of postmilking teat dips. J. Dairy Sci. 73:2580-2585.

IDF. 1993. Determination of nitrogen content. Standard no. 20B. Int. Dairy Fed., Brussels, Belgium.

IDF. 1995. Enumeration of somatic cells. Standard no. 148A. Int. Dairy Fed., Brussels, Belgium.

Le Roux, Y., O. Colin, and F. Laurent. 1995. Proteolysis in samples of quarter milk with varying somatic cell counts. 1. Comparison of some indicators of endogenous proteolysis in milk. J. Dairy Sci. 78:1289-1297.

Le Roux, Y., F. Laurent, and F. Moussaoui. 2003. Polymorphonuclear proteolytic activity and milk composition change. Vet. Res. 34:629-645.

Leitner, G., M. Chaffer, A. Shamay, F. Shapiro, U. Merin, E. Ezra, A. Saran, and N. Silanikove. 2004. Changes in milk composition as affected by subclinical mastitis in sheep. J. Dairy Sci. 87:46-52.

Leitner, G., M. Chaffer, S. Zamir, T. Mor, A. Glickman, M. Winkler, L. Weisblit, and A. Saran. 2001. Udder disease etiology, milk somatic cell counts and NAGase activity in Israeli Assaf sheep throughout lactation. Small Rumin. Res. 39:107-112.

Leitner, G., O. Krifucks, U. Merin, Y. Lavi, and N. Silanikove. 2006. Interactions between bacteria type, proteolysis of casein and physico-chemical properties of bovine milk. Int. Dairy J. 16:648-654.

Leitner, G., N. Silanikove, and U. Merin. 2008. Estimate of milk and curd yield loss of sheep and goats with intrammamary infection and its relation to somatic cell count. Small Rumin. Res. 74:221225.

Moussaoui, F., F. Laurent, J. M. Girardet, J. L. Humbert, S. Gaillard, and Y. Le Roux. 2003. Characterization and proteolytic origins of specific peptides appearing during lipopolysaccharide experimental mastitis. J. Dairy Sci. 86:1163-1170.

Moussaoui, F., I. Michelutti, Y. Le Roux, and F. Laurent. 2002. Mechanisms involved in milk endogenous proteolysis induced by a lipopolysaccharide experimental mastitis. J. Dairy Sci. 85:2562-2570.

Papoff, C. M., A. J. R. Law, D. G. Dalgleish, and R. L. Campus. 1993. Determination of the composition of ovine casein by anionexchange FPLC. Sci. Tecn. Latt. Cas. 44:273-291.

Ribadeau-Dumas, R., and R. Grappin. 1989. Milk protein analysis. Lait 69:357-366.

Rowland, S. J. 1938. The precipitation of the protein in milk, I caseins, II total proteins, III globulins, IV albumin and proteose-peptone. J. Dairy Res. 9:31-41.

SAS Institute. 1999. SAS Users' Guide: Statistics. Version 8.1 ed. SAS Inst. Inc., Cary, NC.

Silanikove, N., U. Merin, and G. Leitner. 2006. Physiological role of endogenous milk enzymes: An overview of an evolving picture. Int. Dairy J. 16:533-545.

Storry, J. E., A. S. Grandison, D. Millard, A. J. Owen, and G. D. Ford. 1983. Chemical composition and coagulation properties of renneted milks from different breeds and species of ruminant. J. Dairy Res. 50:215-229.

Urech, E., Z. Puhan, and M. Schällibaum. 1999. Changes in milk protein fraction as affected by subclinical mastitis. J. Dairy Sci. $82: 2402-2411$ 